\title{
Guerreiro Ramos's Intellectual Trajectory in the U.S. as Seen Through his Writing
}

\author{
Mario Bick
}

Bard College, New York, USA

E-mail:mario.bickilha@gmail.com 
Abstract

Largely overlooked in the extensive recent literature on Guerreiro Ramos are the articles he published in English during his years of exile in the United States. I argue here that these articles demonstrate his impressive ability to adapt to changing intellectual possibilities. In these articles, he shifted from an erudite focus on Brazil and Latin America to a full engagement with the American literature in Sociology and especially in Public Administration, while sustaining his role as a creative critic. These articles, many of which had been anticipated in his Brazilian writings, were incorporated in his book, The New Science of Organizations. With the amnesty of 1978, he returned to Brazil and to Brazilian issues, and to publishing in Portuguese. His impact in the U.S. outside of the University of Southern California seems limited, while his rediscovery in Brazil has been dramatic. I suggest possible reasons for this.

Keywords: Guerreiro Ramos. Public Administration. Intellectual Trajectory. Parenthetical Man.

\section{Resumo}

Muito negligenciados, na recente e extensa literatura sobre Guerreiro Ramos, são os artigos que ele publicou em inglês durante seu exílio nos Estados Unidos. Argumenta-se aqui que esses artigos demonstram sua impressionante habilidade de se adaptar a possibilidades intelectuais mutantes. Nesses artigos, ele trocou o foco erudito sobre o Brasil e a América Latina por um engajamento total com a literatura americana de sociologia e, especialmente, com a de Administração Pública, ao mesmo tempo em que mantinha seu papel como um crítico criativo. Esses artigos, muitos dos quais tinham sido antecipados em seus escritos brasileiros, foram incorporados em seu livro, The New Science of Organizations (A Nova Ciência das Organizações). Com a anistia de 1978, ele retornou ao Brasil e às questões brasileiras, por isso voltou a publicar em português. Seu impacto nos Estados Unidos e fora da University of Southern California parece limitado enquanto seu redescobrimento no Brasil tornou-se dramático. Sugerem-se as possíveis razões disso.

Palavras-chave: Guerreiro Ramos. Exílio. Administração Pública. Raça. 


\section{Introduction}

lberto Guerreiro Ramos spent about one third of his professional
life in the United States. During that time he published at least six articles and one book in English, The New Science of Organizations (1981) (published in Portuguese in 1989), which he saw as the major statement of his ideas. While this book has received extensive commentary from Brazilian and American scholars, his articles have been largely ignored (with the exception of Soares, 1995, p. 45-47; Ventriss; Candler; Salm, 2010). The lack of discussion of his articles is understandable since it seems to have been assumed that they were efforts to develop ideas later incorporated into his book. They were published in English (though some, after his death, were translated and published in Brazil (Ventriss; Candler; Salm, 2010, p. 111). These articles preceeded Guerreiro Ramos's return to Brazil, and in a sense, his rediscovery by Brazilian scholars. While most accounts dealing with Guerreiro Ramos in the 1950s and 1960s recognized his importance in Brazil in the development of both sociology and public administration education during this period, his work seems to have been largely forgotten or ignored after he went into exile in 1966. Contrastively, it has been argued that his influence in the United States following his return to Brazil in 1978 and his death in 1982, was never significant beyond the University of Southern California School of Public Administration, and his many students and colleagues, Brazilian and American (Cavalcanti et al., 2014; Ventriss; Candler, 2005).

His return to Brazil after amnesty was proclaimed has led to a revival of interest in his work, republication of early books, with new introductions, and the translation into Portuguese of his book 
and some articles, almost all of them appearing after his death. In addition, he produced new introductions to earlier books and a number of newspaper articles presenting his ideas. This was a venue he had used in his youthful Bahian years, and continued to use effectively in his role as a public intellectual during his years in Rio.

The approach I am taking here is to examine Guerreiro Ramos's American publications as revealing a trajectory toward defining himself primarily as a theorist of public administration from a sociological perspective, separating himself from Brazil, and from the issue of racism in Brazil, and embedding himself in public administration and social science disciplinary discourses as opposed to his earlier writings as a cosmopolitan sociologist, social scientist and public intellectual.

First, as has been noted, race and racism as a topic and a cause are totally absent in the American writing. Second, Brazil and Latin America disappear from his publications, with the exception of three early articles published in English (Guerreiro Ramos, 1970; 1971a; 1973) which discuss modernization in Latin America, within which he cites two of his own publications, some publications by Latin American writers, and an impressive number of European and American authors, continuing the erudition which he was well known for in Brazil. The rest of his American publications do not mention Brazil, or cite any Brazilian authors other than himself.

The trajectory I propose begins with his article "Modernization: Toward a Possibility Model" (Guerreiro Ramos, 1970). It was originally presented as a paper sometime between 1968 and 1970 at the $45^{\text {th }}$ session of the Institute of World Affairs, and was published in the proceedings of the Institute in a volume edited by two professors at USC. It is marked by his critiques of existing theory, his originality in discussing development theories, distinguishing between possibilistic theories, 'Theory $\mathrm{P}^{\prime}$, and deterministic theories (laws of historical necessity), 'Theory N'(Guerreiro Ramos, 1970, p. 22-23).

In the same year (1970) he presented a paper "The New Ignorance and the Future of Public Administration in Latin America" (Latin American Research Review, 1970, p. 176) at a conference at the University of Texas, chaired by Lawrence Graham, entitled 
"Administering Revolutionary Change in Latin America". This paper was published in Thurber and Graham's edited volume Development Administration in Latin America (Guerreiro Ramos, 1973, p. 382422). This article focuses on public administration and presents themes which are incorporated in later articles and in his book. These themes are reflected in the following quotes: "The 'new public administration' is characterized by the perception of the gap between what we know and what we must know to fulfill the specific duties of our profession" (Guerreiro Ramos, 1973, p. 384); “action-research oriented practitioners no longer support the idea, as Hegel and Marxians did, of a unilineal social development" (Guerreiro Ramos, 1973, p. 385), i.e. they must approach the future through a possibilistic approach. "There is a need in our field for a systematic study of the problem of unity of theory and practice" (Guerreiro Ramos, 1973, p. 385, n. 6). "We have now...the technical capacity to do very nearly anything we want $[\ldots]$ wealth has a new meaning. It is no longer exclusively nature-made. It is essentially man-made [...] The world economy exists [...] it can be managed as a whole, and the notion of a gross world product is becoming an analytical tool" (Guerreiro Ramos, 1973, p. 388). "Mankind as a whole has already passed the stage of necessity" (Guerreiro Ramos, 1973, p. 391). He later rejects this optimism in his book. The theme of self actualization appears in a section entitled "Commitment to Human Growth" (Guerreiro Ramos, 1973, p. 393-402) a major concern of his book. He states here that "The abolition of the fundamental scarcities that have thwarted human development throughout history is now a concrete possibility" (Guerreiro Ramos, 1973, p. 393).

He claims that "We are reaching a point in history where...the administration of things makes unnecessary the administration of persons" (Guerreiro Ramos, 1973, p. 394). "Dropouts and hippies are today living critics of the modern organization. They express in acute terms the general malaise disguised under the conformity of those who apparently fit the modern organizations. Thus organization theory must be subsumed under a theory of human development with the healthy personality as one of its paramount concerns" (Guerreiro 
Ramos, 1973, p. 398). "Without a commitment to humanistic values, social science, and therefore administrative science (emphasis mine) is meaningless" (Guerreiro Ramos, 1973, p. 399). “[...] corruption in Latin American countries may perform the 'valuable function of a 'hedge' and safeguard against the full losses of a bad economic policy" (Guerreiro Ramos, 1973, p. 410).

Finally he turns to Brazil, and especially to EBAP (Guerreiro Ramos, 1973, p. 419-422) which "[...] has given special attention to the study of institution building". He notes that four of its professors did their Ph.Ds at USC, implicitly under his own supervision (Guerreiro Ramos, 1973, p. 421, n. 96). This article cites a wide range of authors, including many American scholars of Public Administration, and clearly shows Guerreiro Ramos's identification with public administration, and his familiarity with the American literature.

In his article "Latent Functions of Formalism in Brazil" published in the Journal of Sociology and Social Research (1971), Guerreiro Ramos notes that this article "relies heavily upon Chapter 6 of my book Administração e Estratégias do Desenvolvimento" (1966). "Formalism", he states, "can be seen as a situation where the letter of the law is not congruent with the actual practice of the citizens" (Guerreiro Ramos, 1971a, p. 62). Following Robert Merton's concept of latent functions (1967) he argues that in Brazil "the army and the Church of Brazil have functioned as an exhaust valve of the social system to the extent that they have provided positions for citizens who otherwise would be marginal to the society (Guerreiro Ramos, 1971a, p. 66), thus, "[...] because of the latent function of formalism, many citizens handicapped in fortune and birth have ascended to high positions in the Brazilian social system" (Guerreiro Ramos, 1971a, p. 67). He cites Emilio Willems (1940), who coined the concept of 'peneiramento' (screening), and examined " $[. .$.$] the$ extralegal and unorthodox processes or channels of social mobility that are collectively accepted as normal" (Guerreiro Ramos, 1971a). These included nepotism, bribery, venality and favoritism (Guerreiro Ramos, 1971a, p. 68). 
He then examines an administrative behavior seen as typical of Brazil, “[...] the jeito [...] getting something, in spite of the legal norm (Guerreiro Ramos, 1971a, p. 72), and points to “[...] a marginal figure of the bureaucracy [...] o despachante" (Guerreiro Ramos, 1971a, p. 73). He concludes by arguing that formalism in peripheral nations, when examined from the standpoint of latent function, is, in essence, a strategy of social change, "[...] to cope with social conflict [...] of ascendant social vertical mobility, of nation building and a strategy of articulating the peripheral society with the rest of the world" (Guerreiro Ramos, 1971a, p. 80).

This is his last publication in English that mentions Brazil. It does so drawing on the classical American structural functional analysis of Robert Merton, demonstrating Guerreiro Ramos's utilization of American sociological theory which he had criticized in his Brazilian writings in conjunction with a dismissal of American social science in comparison with the French and German sociological tradition. This impressive analysis signals an increasing accommodation to American social science thought, and a shift from a sociological identity to that of a public administration theorist.

The information available to me indicates that between 1966 and 1972 Guerreiro Ramos lectured or participated in at least 17 conferences:

a) 1966 California State College (which one unclear);

b) 1967 Stanford University Faculty Club; joint meeting of Stanford and University of California at Berkeley faculty. Paper: "Toward an Ecumenical Social Science";

c) 1967 University of California at Santa Barbara;

d) 1968 University of California Los Angeles (UCLA);

e) 1968 University of California Riverside, Colloquium on Brazil-Portuguese Africa, Sponsored by UCLA Latin American Research Program, UCLA African Studies Center, and Latin American Research Program, University of California Riverside. Participants included major Brazilian and American scholars, for example Roger Bastide, Rene Ribeiro, Ralph Della 
Cava, Robert Levine, Shepard Forman and Marvin Harris. Latin American Research Review (1968, p. 119);

f) 1968 University of Southern California, "Typology of Nationalism in Brazil: a Case Study of Political Breakdown" (Mimeo);

g) 1969 University of Southern California (USC) School of Business Administration;

h) 1969 Columbia University;

i) 1969 Temple University;

j) 1969 Rutgers University;

k) 1969 Brigham Young University;

l) 1969 San Diego State College, Institute of World Affairs and Dept. of Political Science;

m) 1970 University of Texas, Austin, Conference: Administering Revolutionary Change in Latin America. Chairman, Lawrence Graham, Dept. of Government. Paper: "The New Ignorance and the Future of Public Administration in Latin America". (Latin American Research Review 1970, p. 176);

n) 1971 Denver, Colorado, National Conference of the American Society of Public Administration;

o) 1971 Syracuse University (probably at invitation of John Honey of the School of Administration);

p) 1972-73 Visiting Fellow, Dept. of Political Science, Yale University (to work with Robert Dahl) Visiting Professor, Wesleyan University;

q) $1972 \mathrm{New}$ York University, conference on "Brazil's International Role in the Seventies" Paper on "International prospects of the contemporary Bonapartist regime" (mimeo).

r) 1972 Annual Meeting of the American Society for Public Administration,"Misplacement of concepts and administration Theory" (published 1978, location unknown).

It is evident that between 1966 when he arrived at USC, and 1972 Guerreiro Ramos was very active giving lectures and participating in conferences. He also made a number of weekend trips to Washington to teach at the Public Affairs Center established there by USC's School 
of Public Administration in 1973. Between 1966 and 1969, to my knowledge, he lectured only at California colleges and universities, which suggests that the USC School of Public Administration may have been involved in generating invitations. His first two published papers also appeared in a book edited by colleagues at USC and in a journal published by USC.

However he soon moved beyond this local venue. His paper at the University of Texas conference in 1970 was later published in a book co-edited by Lawrence Graham, who had discussed Guerreiro Ramos's work in his book, Civil Service Reform in Brazil (1968, p. 5664; 95-98). Guerreiro Ramos's activities during the period 1969-1973, which include his sabbatical year at Wesleyan and Yale, were mostly on the East Coast, and except for the 1972 conference which was on Brazil, his presentations addressed the topic of Public Administration.

While I have found no evidence of other conferences or lectures after 1972, it seems unlikely that during the following 6 years in the U.S. he made no further trips or appearances. His final papers may have been presented first at professional meetings. The information on this aspect of his professional life in the U.S. is based on resumes provided by his son, Alberto Guerreiro Ramos, which seem incomplete for the period 1973-1978. For example, he claims, in his interview with Alves and Lippi that he had also visited Harvard (1995, p. 176).

Guerreiro Ramos's invitations to the East Coast, and his visiting positions at Wesleyan and Yale indicate that his status and reputation in the U.S. had increased. Clearly he had moved beyond the orbit of USC and had become a nationally respected figure in the field of public administration. His ideas were making a national impact, especially on Public Administration theory. In 1971 "The Parenthetical Man" was published in the Journal of Human Relations. He described this model as "essentially normative" (1971, p. 465), and described the parenthetical man as "[...] able to estrange himself from the familiar, the quotidian. He deliberately tries to become an outsider in his own social milieu to maximize his understanding of it [...] He is expert in detaching himself" (Guerreiro Ramos, 1971, p. :471). Guerreiro Ramos noted “many similarities between 'protean man' and 
'parenthetical man'" (Guerreiro Ramos, 1971, p. 472) and compared him to the anthropologist who "transacts with a society where he is an outsider engaged in participant observation" (Guerreiro Ramos, 1971, p. 473). He is "basically concerned with the full actualization of his potential." (Guerreiro Ramos, 1971, p. 475-476). He had already proposed this idea in his Redução Sociológica in 1965. It seems to be a further development of his poetic model of 'in-betweenness' (ser dois), but now as a response to the problems of industrial capitalism, and the possibility of an active distancing from its constraints - the epistemological capacity for independent critical distance. The concept appeared elsewhere in his writing, and has been utilized by other writers, mainly Brazilians. It permeates his book The New Science of Organizations, and seems to represeent his claim for his own analytical position. With the exception of one reference to Freud, the article draws exclusively on American sources.

In "Models of Man and Administrative Theory" (1975, p. 54, n. 1) Guerreiro Ramos noted that the subtitle of the article was "The Rise of the Parenthetical Man". This article was a modified version of his earlier paper. Here he specifically used the concept as it might apply to administrative theory. The next three articles originally appeared in Public Administration publications: Administration and Society (2) and Public Administration Review (2). "The Theory of Social Delimitation: a preliminary statement" (Guerreiro Ramos, 1976, p. 249) examined the possibilistic organizational framework for the parenthetical man. Drawing heavily from the counter cultural, anti capitalism, largely American social science and popular social science critiques of the 1960s and 1970s, he described his argument as opposed to "[...] administration, political science, economic and social science in general" which "[...] largely assume that the market is the cardinal category for ordering personal and social affairs". He proposed "[...] to delineate a model for social systems analysis and design in which the market is considered a necessary, but limited and regulated social enclave" (Guerreiro Ramos, 1976, p. 249). In such a social world, "[...] there are places for the individual's actualization free from superimposed prescriptions" "[...] In these 
alternative places, true personal choice is possible (Guerreiro Ramos, 1976, p. 251). He introduced the concept of 'isonomy', "settings in which its members are peers" (Guerreiro Ramos, 1976, 262), and of 'phenonomy', "[...] settings for people to release their creativity $[\ldots]$ " in which "[...] its members are engaged only in self-motivated works" (Guerreiro Ramos, 1976, p. 264). While "output of activities...can eventually be marketable, economizing criteria are incidental $[\ldots]$ " (Guerreiro Ramos, 1976, p. 264). He termed the paradigm presented in the article 'Paraeconomy', "[...] an approach to social systems analysis and design in which the scope of economies in the society is delimited, instead of constituting the only social force and criterion" (Guerreiro Ramos, 1976, p. 266). He drew inspiration from Polanyi and his colleagues, in their delineation of non-capitalist substantive economics, i.e. exchange and redistributive economies (Polanyi, 1971; see also Polanyi; Arensberg; Pearson, 1957; Sahlins, 1972).

Part of Guerreiro Ramos's final published article listed above: "Misplacement of Concepts and Administrative Theory", was originally presented on a panel at the annual meeting of the American Society for Public Administration in 1972, and updated for publication in 1978 (Guerreiro Ramos, 1978, p. 555, n. 1). It constituted a critique of administrative theory which, he argued, "[...] will be crippled if it continues to indulge in the practice of unqualified borrowings from other disciplines, theories, models and concepts alien to its specific task" (Guerreiro Ramos, 1976, p. 550). In large part this article examined Public Administration theory from the perspective of the philosophy of science, targeting certain popular uses of theory in sections entitled "the fallacy of corporate authenticity" (Guerreiro Ramos, 1976, p. 551), "the misunderstanding of alienation" (Guerreiro Ramos, 1976), and "organizational death, a misnomer" (Guerreiro Ramos, 1976, p. 553). For the first time, he mentioned that some of his arguments here were included in "The Behavioral Syndrome", and "A Substantive Approach to Organization: epistemological grounds", Chapters 3 and 4 "in my forthcoming book, The New Science of Organizations" (Guerreiro Ramos, 1976, p. 57, n. 49), his first reference to his book. 
Thus Guerreiro Ramos's intellectual trajectory in the U.S. seems clear. Most of the subjects of his articles were first formulated in his Brazilian publications, especially "A Redução Sociológica" (1965), and most were incorporated in his book "The New Science of Organizations" (1981). Brazil and Latin America dropped out of his writings in two senses: first, as the empirical basis for his theoretical analysis, and second, from his bibliographies, which had no Latin American or Brazilian citations, except for occasional references to his own work (in his book, for example, he cited his own work three times, twice for one article). This U.S. trajectory contrasts with the erudite and cosmopolitan display of references in his early articles and in his Brazilian publications, which are redolent with references to French, German, Latin American and Brazilian literature in his footnotes and bibliographies. Instead, his references in his U.S. writing were unerringly to the American social science and Public Administration literatures, and the articles were published in Public Administration journals.

His book departed from this trajectory and returned to the use of European as well as American authors, and once again reflected his erudition and ability to effectively couch his arguments in others' research and theory, including that of many Americans. His book and some of the articles take him into new analytic spaces: for example, non-market economic models based on the work of Polanyi (1971), and Sahlins (1972) on formal vs. substantive economic models, and a shift in his understanding from that of the human capacity to produce all that is needed, to a strong position that we must accept ecological limits to production and distribution of needs and the implications of ecological limits.

His positions in the book seemed to derive importantly from his extensive knowledge of American critics of American society in the academic and popular writings of 1960s and 1970s, their counter cultural and anti-market arguments and their research supporting these arguments within the fields of sociology, anthropology, political science and social psychology/psychoanalysis. His book is suffused with humanism and the optimistic belief that human societies can, with 
the guidance of Public Administration, achieve humane societies and self-actualized individuals. Reading this book, if I didn't know that Guerreiro Ramos was a Brazilian, I would have thought he was an American intellectual, a reformer whose book echoed other writings of the period. In contrast to Brazil where his books were often based on earlier newspaper articles, this book drew on his professional articles. It appears that if the amnesty had not been proclaimed in 1978, he might well have continued this trajectory of increasing adaptation to the American academic scene.

Would his consistent self-identification as a Brazilian have lessened if he had not been able to return to Brazil? It is not clear when he began writing his book, but by 1978, the year of the Amnesty, it was underway, and his articles in English end in that same year. In Brazil, where he always presented himself as a critic of U.S. social science scholarship, he commented in his 1981 interview with Alves and Oliveira (1995) he stated, consistent with his statements before his exile, that his book was for Brazilians, and that "[...] e contra toda a ciência Americana" (Guerreiro Ramos, 1995, p. 159). Yet David Mars, a former student at USC, reports that Guerreiro Ramos had once he told him, "David, do you know that only the Americans are writing good sociology?" (Cavalcanti et al., 2014, p. 179). The evidence of his American publications suggests that his work during this period was heavily influenced by American social scientists. On his return to Brazil to develop a Public Administration masters program at UFSC, and to lecture (I could find no record of to whom or where), he resumed writing and being interviewed for newspaper articles.

Only one article, on Reagan's Política Econômica, drew on Guerreiro Ramos's American experience (Soares, 2005, p. 14-15). He claimed that "jamais se afastava do Brasil e que admitia permanecer longos períodos aqui" (Soares, 2005, p. 13). Soares noted further that Guerreiro Ramos "[...] critica o disciplinarismo dominante [...] abandona a sociologia e rejeita as ciências sociais em sua designação moderna, referindo-se à ciência social, no singular [...]" and stated that "[...] administração fazia parte da ciência social" ( Soares, 2005, p. 9697). Guerreiro Ramos claimed that he "mantinha sua independência 
intelectual" in the U.S., seeing it as qualitatively deteriorating, spendthrift, and polluting its resources, and as having an inadequate political economy. On the other hand he also described the U.S. as "[...] o país mais inovador da história contemporânea" (Soares, 2005, p. 99). Ironically in his interview in 1981 he had commented that "Hoje a minha ascensão como teórico nos Estados Unidos é uma beleza [...]", and that in the U.S. "É uma vida muito gostosa, muita tranquila. Todo dia é um gozo, um enjoyment" (Abreu; Oliveira, 1995, p. 176). Later in the interview he also commented that " $[. .$.$] a cidade do Rio de Janeiro$ é pura entropia. É impossível viver nessa cidade. Vocês não têm ordem [...]". "É preciso que você viva numa sociedade normal para saber que tudo é anormal" (Abreu; Oliveira, 1995, p. 178). "Não posso viver no Brasil" (Abreu; Oliveira, 1995, p. 179). Thus on his return to Brazil he expressed contradictory views of both the U.S. and his native country and ambivalence about his relationship to them.

However, it also triggered a revival of interest in his ideas. His book was republished in Portuguese (1989), and at least four of his articles were also translated (Ventriss; Candler; Salm, 2010, p. 111). After his return to Brazil, and especially after his death theses, articles, books and symposia examined his work. But rarely his American writings. This all indicates that having been largely forgotten in Brazil, interest in him has grown, while elsewhere he remains rather marginal, except for his former students at USC (Ventriss, Candler; Salm, 2010, p. 110).

He submitted his book proposal to 14 publishers until the University of Toronto Press accepted it, perhaps encouraged by assistance from UFSC and the publication fund at the University of Toronto Press (Ramos 1981; cataloguing page. They ended their reviews as follows:

- James Fesler, Yale: “The author's analysis of our present discontents and their roots is powerful. His sketch of distinct enclaves seems unlikely to carry us far toward a new science of organizations". (The American Political Science Review, 1982, p. 741)

- Andrew Weiss, School of Business, Indiana University, in a generally favorable review notes that "the theory 
it presents is not persuasive". (The Academy of Management Review, 1986, p. 217)

- Kenneth Benson, University of Missouri: "As often happens in normative theorizing, however, Ramos failed to connect the proposed forms of organization to real social relations that determine the possibility of realizing them". (American Journal of Sociology, 1984, p. 977)

- Thomas Lewis of McMaster University, most critical of the book: "But the result is mainly argument by citation; a gathering up of snippets of anti-market comments which are flung out against contemporary social theorists. Thus, ideas that should be developed into cogent criticisms of the market mentality shrink instead into platitudes and all too frequent ad hominem. The argument is generally repetitive and undisciplined, and the periodic promise of insightful analysis is too soon followed by polemical exhortation and condemnation". (Canadian Journal of Political Science 1982:837). "It is seldom easy to separate new ideas from old, but I believe it is safe to say that this book contains few ideas that are new, and it obscures much of what we may need to know about ideas that are old". (American Journal of Sociology, 1984, p. 839)

Most reviewers had positive things to say about the book. They noted his breadth of knowledge and ability to synthesize. The critiques tended to pick up on his tendency to over-footnote and to cite sources difficult to relate to organizational theory in public administration. One journal reviewer had rejected an article he submitted, arguing that his scholarship was too sophisticated for an American audience (Ventriss; Candler, 2005, p. 352). Too sophisticated, too complex, too difficult to understand. Some reviewers pointed to the difficulty of operationalizing his ideas. But, lurking within the critiques is also the suggestion that he is often not saying anything new to American scholars.

How to think about the negative American response to his book and the continuing ignoring of his ideas in the U.S. since its publication? My ability to judge this situation is limited by the fact that my discipline is anthropology and that I am largely unfamiliar with the literature in the discipline of Public Administration. But the 
discipline he was writing about has been described as pragmatically driven, instrumental and utilitarian in its goals and practice, based on instrumental rationality, provincial and parochial, and relatively unconcerned with its philosophical basis. It has been noted to take a cavalier attitude to the conceptualization of concepts and their appropriate application. Guerreiro Ramos's writings formed a body of systematic critiques of this literature.

His background with government as a researcher, adviser to presidents, black movement activist, sociologist, and one of the first professors of the School of Public Administration in Rio gave him a unique experience and perspective on the nature of organizations and this led him to see the necessary relationship between theory and practice, a background that few if any of his American disciplinary colleagues shared (and many of his students admired). His publications in English provided critiques of current thought and practice, but for the most part served only as warnings, when what he hoped for was a more radical impact on the field, a subjectivist approach to organizations in the interests of human self-realization. But he was not clear about how to achieve these goals, contrary to the clear aims of his market-oriented critical peers, whose goals were far more limited.

Still, why the lukewarm response to those ideas? There is an important point about his citations in the book, which I have not seen discussed, and which speaks to American reviewers' comments that he wasn't saying anything new. The book, and his articles in English, were written in the years after the rise of the counter-culture in the U.S, the Beats, the Hippies and the communal movements, all of them emerging as radical critiques of market capitalism and the triumph of conformity, and all driven as well in the 1960s and 1970s by critiques of the war in Vietnam. These movements drew on a number of active philosophical, economic, psychological, sociological and social psychological writers, including Herbert Marcuse, Dennis Wrong, C. Wright Mills, Robert J. Lifton, David Riesman, Kenneth Burke, Hanna Arendt, John Kenneth Galbraith, R.D. Laing, William H. Whyte, Eric Fromm, Karl Polanyi and Paul Goodman. All of these authors are cited in his book, and had influenced his ideas. Many of these authors 
were new to Guerreiro Ramos, but their work and ideas were widely known and discussed in the U.S. in both the academic press and in the broader world. As a graduate student and young professor in New York city and at the University of Massachusetts at Amherst during these years, I was familiar with most of the American literature he cites, except for the specialized literature of Public Administration. I believe that familiarity with these ideas was an important reason that American critics of his book characterized it as containing nothing really new. In contrast, these authors and their ideas were relatively new for Brazilian readers in the 1990s.

Everyone seems to agree that his impact in Brazil was far greater than in the U.S. His discursive style, and his ideas drawn largely from an American social science literature of the 1960s and 1970s were new to many Brazilian readers, which might help to explain his more positive impact on readers in Brazil. The issue of Guerreiro Ramos's greater influence in Brazil has also been assessed through compiling citations to his work in his English and their Portuguese translations (Ventriss; Candler; Salm, 2010, p. 111). Overall, the data show far more citations to the Portuguese versions than to the English versions (the original versions) which is taken by the authors to indicate his greater appeal and importance in Brazil than in the U.S. These data are certainly suggestive, although they are problematic in that we don't know what period is covered in the survey. The fact that many of the Portuguese versions appeared later than the English originals, during the revival of interest in his work following his death, may have significantly affected the count. But the conclusions are suggestive in terms of Guerreiro Ramos's standing in the two countries.

Former students who teach public administration in the United States, reflecting on his importance more than 20 years after his death, agree on his brilliance as a teacher, his charm and erudition, his commitment to a social science, rather than a disciplinary approach to Public Administration. They agree that he shook up Public Administration scholars at USC, as he had in Brazil, by urging more robust theorizing as well as critical distance. But they have also noted that in the U.S. at least, the success of this approach to a very pragmatic and 
utilitarian field has been strongest within USC, and limited beyond it (Ventriss; Candler; Salm, 2010), and that outside of his former USC students and colleagues, he has had little impact on American Public Administration theory, practice, and teaching (Ventriss; Candler, 2005; Cavalcanti et al., 2014).

Those who downplay his influence in the U.S. should consider the significance of his many talks and participation in organized associational panels and other by-invitation events, which may speak to more influence than Ventriss, Candler and Salm (2010) concede.

His American writings are important because, as I have shown, they impacted on the work and thinking he was doing before he left Brazil, and on his later publications. His work and interests responded to American research and theory. Despite his statements to the contrary, he became at least partially Americanized, and if the military dictatorship in Brazil had not offered amnesty, he probably would have remained in California for many more years. On his return to Brazil he seemed to re-Brazilianize (note that he published nothing further in English after 1978). I want to argue that this shift was characteristic of the highly adaptive character of his life, first in Bahia, then in Rio, in Los Angeles, and finally back in Brazil. Always seeing himself as an in-betweener, he functioned as a Protean man, in Lifton's terms. He was the parenthetical man in each context, and he noted this strategy's similarity to the Protean Man, whose ability to take on new identities gave him great adaptive flexibility. Ramos himself states this very directly in his 1981 interview, when he states: “Eu sou eu. Eu estou onde meu interesse está. Onde não está, não existe". (Abreu; Oliveira, 1995, p. 159).

Guerreiro Ramos's years in the United States are remarkable for his ability to dramatically succeed as a teacher, his rapid and productive absorption, engagement and creative utilization of the American explosion of a critical political social science that he transmitted to Brazil. He was remarkable in his control of English and the lucidity of his writings. His contributions to theory in Public Administration are important both for their critique of inadequate conceptualization, and the impact of his philosophical and social science approach on his discipline to which he dedicated the years in the United States, and 
in his final years, to the teaching of Public Administration in Brazil is ongoing in Brazil. This in-betweeness left his mark both in the U.S. and in Brazil.

His early articles were in the European style; erudite, cosmopolitan, drawing on literature in at least three languages other than Portuguese. He was an impressive intellectual, not that common among his Public Administration colleagues and exciting to his students and colleagues at USC. In the 1970s he accommodated to the U.S. critical style, and its authors, citing almost exclusively American Public Administration sources. But he reverted in his book to what was for American readers his most difficult form. All the ideas in his book were not original, but they were both original in presentation and worth saying. Certainly Brazilians thought and think this is the case. It is significant that so many years after its publication his work has received such extensive and serious attention, in terms of publications and symposia both in the U.S. (Candler; Ventriss, 2006) and in Brazil. Honoring him now, as we are doing, is to honor and value his ideas as vital and important more than 30 years after their publication. This was made possible, ironically, by the weakening of the very military dictatorship in Brazil which had forced him into exile, and which now in allowing him to return gave him time to reengage with his Brazilian audience which has been very responsive to his work.

\section{Postscript}

There is so much we don't know about Guerreiro Ramos's American period: did he speak at more venues than those listed in his C. V., after 1972 and especially following the amnesty in 1978? Are there manuscripts that he was working on, or had completed when he died, and did his earlier mimeo lectures survive? With whom did he correspond in the U.S., in Brazil, and elsewhere? Had he begun to write his memoir and his planned rewriting of the history of Brazil, as mentioned in his 1981 interview (Guerreiro Ramos, 1995, p. 177). How did his appointment at UFSC come about, and what was his impact there? What syllabi did he use in his courses at USC and at UFSC? His spoken English was good, but I have seen no information as to whether 
he wrote his articles and his book in English; he never acknowledged a translator. Given the rapid expansion of literature about him, some of these questions may have been answered. And much more will undoubtedly be discovered in his archives, some of which are stored at the USC library, but most of which are held by his son, Alberto, at his home in the U.S. It would also be useful to interview Americans currently working in the field of Public Administration as to how they view his work today. Answers to these and other questions will allow for a fuller and more nuanced understanding of this "American period" in his productive life.

\section{Acknowledgments}

To Ilka Boaventura Leite for her central role in organizing this conference and its publication. To Elisa Larkin Nascimento, Ariston Azevedo,and Carolina Peçanha in Brazil for their various forms of assistance. To Jeff Katz and Jane Dougall of the Bard Library, and Melissa Germano for providing me with information and publications. And to Diana Brown, whose editorial skills and support contributed much to this article.

\section{References}

BENSON, J. Kenneth. Review of The New Science of Organizations. American Journal of Sociology, [S.l.], v. 89, n. 4, p. 926-977, 1984.

CANDLER, G. G.; VENTRISS, C. Symposium on The destiny of theory: Beyond the New Science of Organizations. Administrative Theory and Praxis, [S.l.], v. 28, n. 4, p. 495-500, 2006.

CAVALCANTI, B.; DUZERT, Yann; MARQUES, Eduardo. (Ed.). Guerreiro Ramos: Coletânea de depoimentos/Collection of testimonials. Rio de Janeiro: FGV, 2014.

FESLER, James W. Review of The New Science of Organizations: a reconceptualization of the wealth of Nations. The American Political Science Review, [S.l.], v. 76, n. 3, p. 741, 1982.

GRAHAM, Lawrence. Civil Service Reform in Brazil. Austin TX: University of Texas Press, 1968. 
GUERREIRO RAMOS, Alberto. [1966]. Administração e Estratégia do Desenvolvimento. Rio de Janeiro: FGV, 1967a.

. A Modernização em Nova Perspectiva: em busca do modelo da possibilidade. Revista de Administração Pública, [S.l.], v. 1, n. 2, p. 7-44. 1967b.

. Toward an ecumenical social science. Paper presented to the joint faculties of the University of California, Berkeley and Stanford University. Stanford: University Faculty Club, May 25, 1968. . Typology of Nationalism in Brazil (a case of political breakdown). Mimeo, USC. 1970 Modernization: toward a possibility model. In: BELING, W. A.; TOTTEN, G. O. (Ed.). Developing Nations: Quest for a Model, [S.l.], v. 44, Proceedings of the $45^{\text {th }}$ Session of the Institute of World Affairs, p. 21-59, 1971a.

. Latent Functions of Formalism in Brazil. Sociology and Social Research, [S.l.], v. 56, n. 1, p. 62-82.1971b.

. The Parenthetical Man. Journal of Human Relations, [S.l.], v. 19, p. 463-487, p. 1972.

. Models of Man and Administrative Theory. Public

Administration Review, [S.l.], v. 32, n. 3, p. 241-246, 1973.

. The New Ignorance and the Future of Public Administration in Latin America. Chapter 15. In: THURBER, C. E.; GRAHAM, L. S. (Ed.). Development Administration in Latin America. Durham NC: Duke University Press, 1976. p .382-422.

. Theory of Social Systems Delimitation: a preliminary statement. Administration and Society, v. 8, n. 2, p. 249-272, 1977.

. Endurance and fluidity: a reply. Administration and Society,

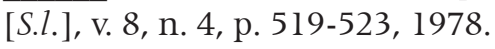

. Misplacement of concepts and administrative theory. Public Administration Review, [S.l.], v. 38, n. 6, p. 550-557, 1981.

Toronto Press, 1989.

The New Science of Organizations. Toronto: University of

. A Nova Ciência das Organizações. Rio de Janeiro: FGV, 1995.

. Entrevista com Guerreiro Ramos. In: OLIVEIRA, Lucia Lippi.

A Sociologia do Guerreiro. (Ed.). Rio de Janeiro: Editora UFRJ, 1996. p. 131-183.

1996.

A Redução Sociológica. $3^{\text {rd }}$. ed. Rio de Janeiro: Editora UFRJ, 
. With a new introduction. Latin American Research Review,

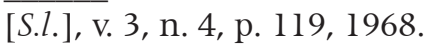

. With a new introduction. Latin American Research Review, [S.l.], v. 5, n. 3, p. 176, 1970.

LEWIS, Thomas J. Review of The New Science of Organizations. Canadian Journal of Political Science, [S.1.], v. 15, n. 4, p. 836-837, 1982.

MARS, David. Interview. In: CAVALCANTI, B. et al. (Ed.). Guerreiro Ramos: Coletânea de depoimentos/Collection of testimonials. Rio de Janeiro: FGV, 2014. p.178-179.

MERTON, Robert. Social Theory and Social Structure. NY: The Free Press, 1967.

POLANYI, Karl. The Great Transformation. Boston MA: Beacon Press, 1971.

POLANYI, Karl; ARENSBERG, Conrad; PEARSON, Harry (Ed.) Trade and Market in the Early Empires. NY: The Free Press, 1957.

SAHLINS, Marshall. Stone Age Economics. Chicago IL: Aldine, 1972.

SOARES, Luiz Antônio Alves. Guerreiro Ramos: a trajetória de um pensamento. Revista de Administração Pública, [S.l.], v. 29, n. 2, p. 32 $50,1995$.

- Guerreiro Ramos: considerações críticas a respeito da sociedade centrada no mercado. Rio de Janeiro: Conselho Regional de Administração do RJ, 2005.

VENTRISS, Curtis; CANDLER, G. G. Alberto Guerreiro Ramos, 20 Years Later: a New Science Still Unrealized in an Era of Public Cynicism and Theoretical Ambivalence. Public Administration Review, [S.l.], v. 65 , n. 3, p. 347-359, 2005.

VENTRISS, Curtis; CANDLER, G. G.; SALM, J. F. Alberto Guerreiro Ramos: the 'in-betweener' as intellectual bridge builder. Organizações e Sociedade, [S.l.], v. 17, n. 52, p. 103-114, 2010.

WEISS, Andrew R. Review of The New Science of Organizations. The Academy of Management, [S.l.], v. 11, n. 1, p. 215-217, 1986.

Recebido em 19/04/2016

Aceito em 20/04/2016 